\title{
Modeling of potential gully erosion hazard using geo-spatial technology at Garbheta block, West Bengal in India
}

\author{
Pravat Kumar Shit ${ }^{1} \cdot$ Rumpa Paira $^{3} \cdot$ GouriSankar Bhunia $^{2} \cdot$ Ramkrishna Maiti $^{3}$
}

Received: 4 February 2015/Accepted: 17 April 2015/Published online: 13 May 2015

(C) Springer International Publishing Switzerland 2015

\begin{abstract}
The gully erosion is the most serious environmental problem in West Bengal in India. Present study focused on delineation the gully affected areas and characterization of geo-environmental factor in the gully affected region to prevent future problems. Ground investigation and geo-spatial data along with bivariate statistical approach were employed to identity the most crucial factors among lithology, dynamic and slope inclination, landuse, aspect, plan curvature, stream power index, topographical wetness index and length-slope factor and also understand the most dominant class of each factor associated the gully erosion in the area under study. All the information were integrated into geographical information system platform and categorized in zones of very high, high, moderate, and low gully erosion susceptibility. Weight index overlay method is used to validate the gully proneness map. Results showed land use factor (barren land and waste land), slope $\left(>20^{\circ}\right)$, topographical wetness index values $(>1.2)$, length-slope index $(>4.00)$, fragments of pebbles, boulder and gravels, older alluvium and lateritic soil play important roles in gully processes. Model validation indicated that the resulting map of areas prone to gully erosion has a prediction accuracy of $88.25 \%$. The methodology adopted for gully erosion proneness mapping
\end{abstract}

Pravat Kumar Shit

pravatgeo2007@gmail.com

1 Department of Geography, Raja N.L.Khan Women's College, Gope Palace, Medinipur 721102, West Bengal, India

2 Bihar Remote Sensing Application Centre, IGSCPlanetarium, Bailey Road, Patna 800001, India

3 Department of Geography and Environment Management, Vidyasagar University, Medinipur 721102, West Bengal, India can be exercised in other gully vulnerability areas that could be an excellent approach to defend the natural resources and progress in the land use conservation.

Keywords Gully erosion - Bivariate statistics · GIS based method $\cdot$ Gully proneness mapping

\section{Introduction}

Gullying is one of the most important parts of the soil erosion processes which largely contribute to the sculpturing of the earth surface over the last decade (Shit et al. 2014). The development of gullies causes the loss of a great amount of soil and can be considered as one of the principal causes of geo-environmental degradation (Vanwalleghem et al. 2005; Marzolff et al. 2011). Additionally, the configuration of gullies entails an amendment of overland flow, a reduction of runoff lag time and an increase in runoff volume. Generally, the growing interest in studying gully erosion reflects the need to increase our knowledge on its impacts and controlling factors that vary under a wide range of causes (Valentin et al. 2005). Erosion generally moves rocky materials or soil particles after the progressions of weathering have wrecked them down into lesser quantities which are transportable. Remote Sensing (RS) and Geographical Information System (GIS) integrated erosion forecast models do not only approximate soil loss but also offer the spatial distributions of the erosion (Okalp 2005). Particularly, generating precise erosion risk maps in GIS platform is extremely noteworthy to establish the areas with high erosion risks (Mitasova et al. 1996) and to expand plenty erosion deterrence techniques (Vrieling et al. 2002).

Appraising the soil erosion rate is crucial for the progression of ample erosion deterrence measures for 
sustainable supervision of land and water resources. GIS technology is precious tools in embryonic environmental models based on data storage, management, analysis, and display. Several studies have been conducted on modelling soil erosion by utilizing RS and GIS technologies (Yuksel et al. 2008; Prasannakumar et al. 2012; Sinha and Joshi 2012; Nasre et al. 2013; Baroudy and Moghanm 2014). However, gully erosion occurrence and behaviour have been limited and reported the spatial distribution of soil loss due to the constraint of limited samples in complex environments. Conversely, mapping of gully erosion in large areas is often very difficult by traditional methods. Earlier studies have investigated the prediction of gully erosion susceptibility zone based on topographical variables (Poesen et al. 2003; Chaplot et al. 2005).

The present study aims to identify dominant the geoenvironmental factors of gully erosion and also to demarcate the probable zone of gully erosion through geo-spatial technology.

\section{Materials and methods}

\section{Study area}

Garbheta block in Paschim Medinnipur district of West Bengal, India is a typical humid region very prone to shallow erosion (Bandyopadhyay 1998; Sen et al. 2004) that may initiate debris flows; similarly, gullies are also very widespread throughout the region, affecting different lithologies and soil types(Shit and Maiti 2012a, b; Shit et al. 2013a, b). The study area of about $35.20 \mathrm{~km}^{2}$, between is located $22^{\circ} 47^{\prime} 12^{\prime \prime} \mathrm{N}$ and $22^{\circ} 56^{\prime} 27^{\prime \prime} \mathrm{N}$ latitude, and $87^{\circ} 13^{\prime} 17^{\prime \prime} \mathrm{E}$ and $87^{\circ} 23^{\prime} 29^{\prime \prime} \mathrm{E}$ longitude (Fig. 1). The climate is tropical type with hot, dry summers, having precipitations concentrated in monsoon period (July to September) (Sen et al. 2004). Mean annual rainfall is about $1450 \mathrm{~mm}$, distributed in 110 rainy days on an average, while mean annual temperature is $28^{\circ} \mathrm{C}$ and mean monthly temperatures range between $8{ }^{\circ} \mathrm{C}$ in January and $43{ }^{\circ} \mathrm{C}$ in June (Shit et al. 2013a). The Shilabati River (Silai) is the main stream, originated from the Chhotanagpur Plate west to east for the length of about $26 \mathrm{~km}$.

Geomorphologically, the study area is a part of the Chhotanagpur plateau margin extremely dissected, discontinued and is characterised and rolling lands. The formation of Pali $(\sim 1000 \mathrm{~m})$ is portrayed by pebbly to coarse-grained micaceous sandstones, medium to fine grained sandstones, and red and green coloured mudstones in the study area (Dey et al. 2009).

The study area falls in a part of passive to extensional cratonic margin in the west of Bengal basin or the western geotectonic province. Niyogi (1970) and Pal (2002) have identified this place as a part of paleo-coastal zone of Bengal basin. The land surface of the study site is characterized by hard and rocky up- lands, barren lateritic covered area and non-arable lands. In the study area, the main erosive processes that affect the landscape are related to runoff waters and mass failures that causes of gully erosion.

\section{Mapping of gullies}

Gullies in Garbheta badland area were mapped in Google Earth from the Digital Globe images of 2013 based on the visual interpretation of the images. Digital layers were saved as KML files from Google Earth. Data created in Google Earth into Arc GIS, the R-statistics freeware was used to convert Keyhole Markup Language (KML) files into shape files ('.shp file format') (Frankl et al. 2013; Dube et al. 2014). Ground truthing was done for the identified gullies in the study area during October to December 2014.

\section{Gully erosion influential factors}

Several factors contribute to gully erosion and they have been well described in the literature, including topographical variables (BouKheir et al. 2007; Kakembo et al. 2009; Conforti et al. 2011; Conoscent et al. 2013; Dube et al. 2014), parent material-soils interactions (Laker 2004; Valentin et al. 2005) and cover management (Boardman et al. 2003; Boardman and Foster 2008; Gómez Gutiérrez et al. 2009a, b). The development of gully erosion proneness models requires the selection of environmental factors able to reproduce the geographical variability of the main factors potentially controlling the phenomenon; for this research, the selection was based on geomorphological knowledge of gully erosion phenomena and on the availability, for the area, of environmental data related to erosion processes. Gully erosion occurrence and behaviour of this phenomenon depends on climate, topography, lithology, soil characteristics and land use (Poesen et al. 2003; Gómez Gutiérrez et al. 2009a, b). Proneness to gully erosion is a function of erodibility of out cropping materials and erosivity of runoff (Conoscenti et al. 2008; Conforti et al. 2011). The present study considered four erodibility and six erosivity variables for determination of gully erosion proneness mapping. The erodibility factor included: lithology/geology, geomorphology, soil and land use-land cover (LULC). The erosivity variables considered as elevation and aspect, plan curvature, stream power index (SPI), topographic wetness index (TWI) and length-slope factor (LS) (Conforti et al. 2011; Dube et al. 2014). All the morphometric characteristics were automatically derived from Advanced Space borne Thermal Emission and 

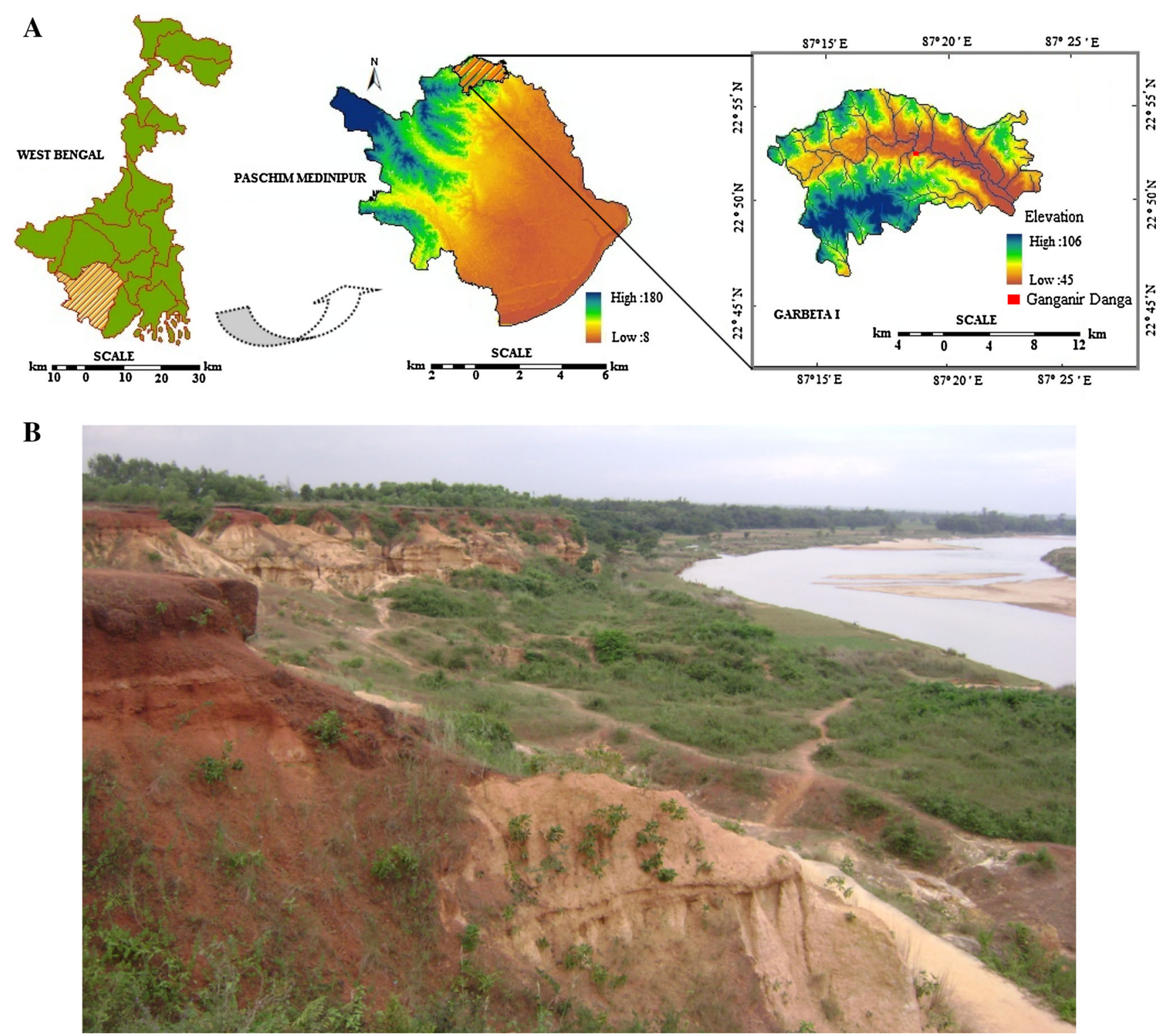

Fig. 1 Location of the study area a elevation map of Garbheta Badland, b partial view of Ganganir Danga at Garbheta badland along the Silai River

Reflection (ASTER), Digital Elevation Model (DEM) data with a $30 \mathrm{~m}$ resampled to $2.5 \mathrm{~m}$ resulation.

Lithology and soil Gully erosion is positively associated to the lithology, of the earth surface. A comprehensive analysis of the major lithological characteristics has been executed by amalgamated data from the geological map of Garhbeta at 1:25000 scale with the data collected from field survey. Soil information was obtained from the soil map of District Planning Map of Paschim Medinipur at 1:25,000 scale with field survey following FAO (1974) classification. First we scanned and geo-referenced these map using ground control points (GCP) by the process of single map/ image rectification in ERDAS IMAGINE $8.5 \mathrm{v}$ and Arc-
GIS software $9.2 \mathrm{v}$, then a polygon vector layer was created and the entire soil groups and lithology map was digitized.

Land use and land cover (LULC) Land use played an important role on the geomorphological stability of a slope. Barren and sparsely vegetated areas are exaggerated by earlier erosion and greater unsteadiness than forests (Dai et al. 2001; Cevik and Topal 2003). The presence of a plant cover lessens intensity of gully erosion, because it decreases the erosive action of surface runoff. A land use map has been generated using Landsat Thematic Mapper data and IRS 1C LISS-III. The images were resampled to a pixel size of $2.5 \mathrm{~m}$. Supervised classification was done using the maximum likelihood classifier (MLC) algorithm of 
ERDAS IMAGINE v.8.5. The maximum likelihood classification algorithm assumes that spectral values of training pixels are statistically distributed according to a multivariate normal (Gaussian) probability density function. Consequently, classification results were then assessed for accuracy using the 2013 Google Earth image of the study area combined with field based ground control-points determined in the study area using a hand-held Garmin GPS (Model: 76CSx, accuracy $\pm 3 \mathrm{~m}$ ). Accuracy assessment of the land cover classes was estimated based on the method followed by Rogan et al. (2002).

Length-Slope factor The length-slope factor (LS) is used to consider the effect of topography on erosion. The topographical parameter depends on the steepness of slope (S) and the length of slope (L). The LS has been calculated based on the equations described by Moore and Burch (1986). Flow accumulation was calculated using the watershed delineation tool of Arcview software 3.2.

$L S=(\text { fa } \times \text { cellsize } / 22.13)^{0.4} \times(\sin \sigma / 0.0896)^{1.3}$

where $f a$ is flow accumulation and is derived from the DEM using a GIS accumulation algorithm (Lee 2004) and $\sigma$ is slope in degrees.

Aspect Aspect is deemed as an important factor in vulnerability studies of denudational processes (Nagarajan et al. 2000). The aspect of a slope can control gully erosion processes, as it controls the exposure to numerous climate conditions and the vegetation cover (Pulice et al. 2009).

Topographical wetness index (TWI) TWI is a function of both the slope and the upstream contributing area per unit width orthogonal to the flow direction (Gumindoga et al. 2011; Dube et al. 2014). The TWI gives the spatial distribution and zone of saturation sources for runoff generation. TWI has been calculated based on the method followed by Moore et al. (1991).

$T W I=\ln [A s / \tan (\beta)]$

where, $A s$ is upstream contributing area and $\beta$ is the slope gradient.

Stream power index The stream power index (SPI) is one of the main dominating factors of slope erosion processes. SPI is a measure of the erosive power of water flow based on the hypothesis that discharge is comparative to the specific catchment area (As). SPI is calculated based on the method followed by Moore et al. 1991. The erosive power of running water controls toe erosion and river notch (Nefeslioglu et al. 2008), and also indicative of the potential energy available to entrain sediment (Kakembo et al. 2009).
$S P I=A s \times \tan \sigma$

where, As is the specific catchment area in meters and $\sigma$ is the slope gradient in degrees.

\section{Gully proneness analysis}

To assess the gully erosion vulnerability, information value method was used outlined by the earlier workers for proneness mapping (Cevik and Topal 2003; Yalcin, 2008). In this method, all the data were obtained in a single platform in GIS environment and the application of a bivariate statistical method was used in this study. This statistical calculation is based on the pragmatic relationships between each influential factor and the allocation of gully areas. The thematic maps generated for each predisposing factor (geomorphology, soil, lithology, land use, elevation, aspect, plan curvature, SPI, TWI and LS) have been transformed in raster format through ArcGIS software. A gully inventory map was developed in order to compute the density of the gully areas for each class of the predisposing factors. The estimated density symbolizes the proneness level of the considered predisposing factor class. A weight value for a parameter class was defined as the natural logarithm of the gullies density class divided by the area of gullies density over the entire study area. In the present study, weight value for a parameter class was delineated as the natural logarithm of the gullies density class divided by the area of gullies density over the entire study area (Yin and Yan 1988; Van Westen 1993; Conforti et al. 2011; Dube et al. 2014).

$W i=\ln \frac{\text { DensClass }}{\text { DensMap }}=\ln \frac{N_{\text {pix }} S_{i} / N_{\text {pix }} N_{i}}{\sum N_{\text {pix }} S_{i} / \sum N_{\text {pix }} N_{i}}$

in which $\mathrm{Wi}=$ weighting value of the class $\mathrm{i}$; DensClass $=$ density of the gullies in the class $i$; DensMap = density of the gullies in the whole study area; $\mathrm{N}_{\text {pix }} \mathrm{S}_{\mathrm{i}}=$ number of pixels that contains gullies in the class $i ; \mathrm{N}_{\text {pix }} \mathrm{N}_{\mathrm{i}}=$ number of pixels within the class $\mathrm{i} ; \sum \mathrm{N}_{\text {pix- }}$ $\mathrm{S}_{\mathrm{i}}=$ total number of pixels that contain gullies in the whole study area; $\sum \mathrm{N}_{\text {pix }} \mathrm{N}_{\mathrm{i}}=$ total number of pixels of the whole study area.

Finally, the weighted overlay index method was used to calculate the proneness value to delineate gully eroded area (Fig. 2) and characterize the badland units. In this method overlay procedures has been performed on reclassified maps in GIS environment. All the information has been resampled into $2.5 \mathrm{~m}$ pixel size in GIS environment. All the layers overlayed by applying the "Raster Calculator" tool in the "Spatial Analyst" extension of ArcGIS v9.2 in order to calculate the potential gully erosion susceptible zone of the study area. The conquered ranges of values have been categorized into five proneness classes based on the natural-breaks of erosion. 


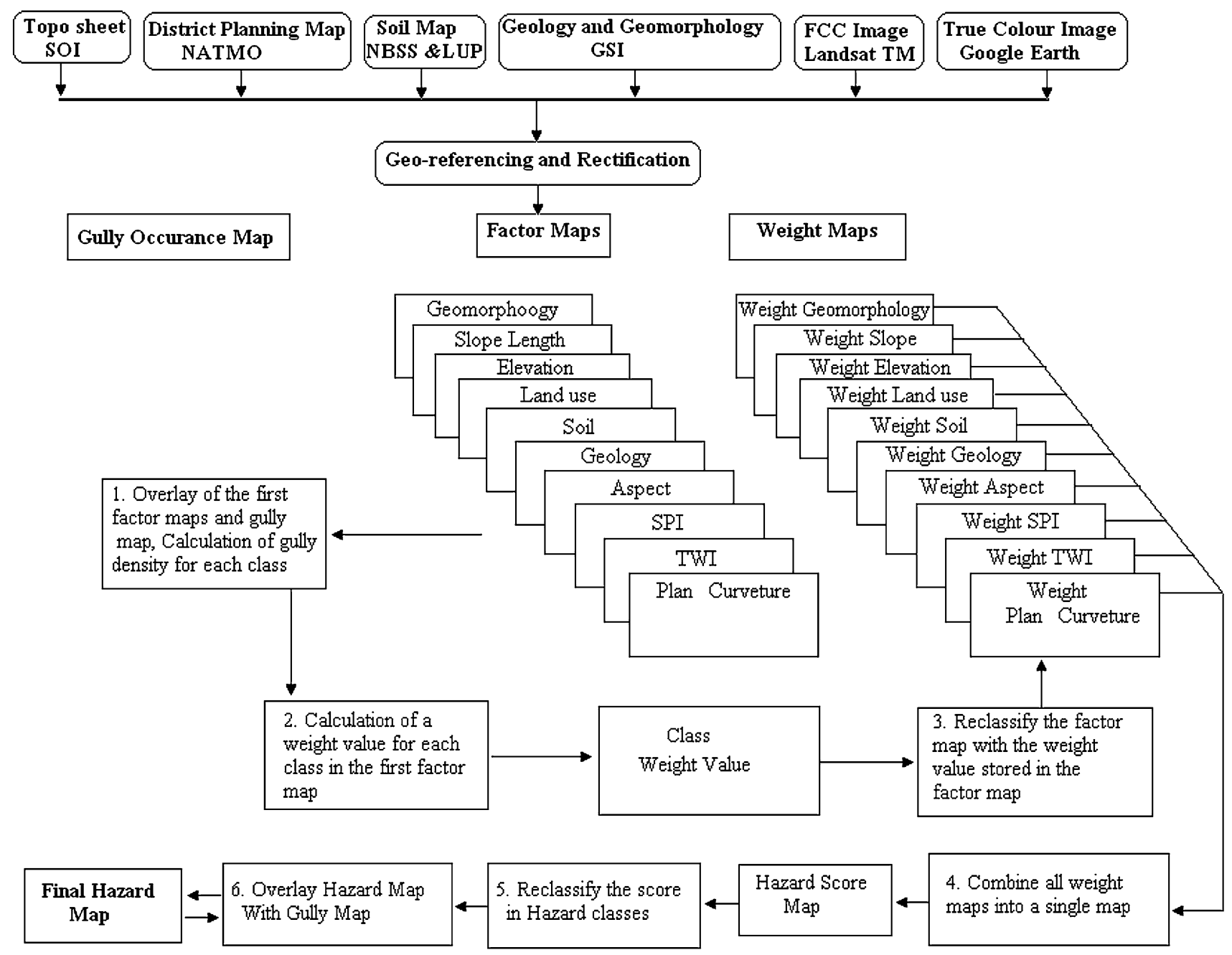

Fig. 2 Flow chart of the methodology (SOI survey of India, NATMO National Atlas Thematic Mapping, NBSS and LUP National Bureau of Soil Survey and Land Use Planning, GSI Geological Survey of India)

\section{Accuracy assessment}

A total of 100 sample sites were selected randomly from recent gully erosion zones in the field to validate gully erosion proneness model. The location of each sample site were recorded through Global Positioning System (GPS). The success rate curve was estimated to assess the ability of gully erosion proneness model and factors considered to predict the gully (Chung and Fabbri 2003). Prediction rate curve is computed for gully distribution patterns (in the training area) for a time point posterior to the training data set's temporal domain. To produce the success rate and prediction rate curve, the estimated index values of all cells were organized in descending order and were allocated into 100 equal classes extending from very high to very low proneness classes. Then the order of cell values were categorized into 100 classes using "quantile" method in ArcGIS, with $1 \%$ cumulative intervals. The gully proneness map derived through weighted index overlay method is also prepared with slicing operation in ArcGIS software. After that, the calculated 100 classes were overlaid and crisscrossed with the set of gullies worn in creating the model (assessment gully group) to regulate the percentage of gully occurrences in each gully proneness class. Finally, the success rate curve was assembled by depicting the susceptible classes starting from the highest values to the lowest values on the $\mathrm{X}$-axis and the cumulative percentage of gullies occurrence on the Y-axis (Remondo et al. 2003). Therefore, the area under the curve can assess the model validation quantitatively.

\section{Results}

\section{Gully erosion processes}

Table 1 represent the density of gully areas and the weighting values obtained using the information value 
Table 1 Weighting value (Wi) distribution for each class of the selected gully occurrence influential factors

\begin{tabular}{|c|c|c|c|c|c|}
\hline Factors & Sub-category & $\mathrm{N}_{\text {pix }} \mathrm{N}_{\mathrm{i}}$ & $\mathrm{N}_{\text {pix }} \mathrm{S}_{\mathrm{i}}$ & Denseclass & $W_{i}$ \\
\hline \multirow[t]{2}{*}{ Soil } & Lateritic soil & 247,455 & 8123 & 0.03283 & 0.091 \\
\hline & Older alluvial soil & 159,000 & 4123 & 0.02593 & -0.146 \\
\hline \multirow[t]{5}{*}{ Geomorphology } & Upland plains & 170,597 & 5170 & 0.03031 & 0.001 \\
\hline & Paradeltaic fan surfaces & 7314 & 28 & 0.00383 & -2.066 \\
\hline & Duricrusts & 5368 & 25 & 0.00466 & 1.875 \\
\hline & Pediments and pediplans & 39,854 & 125 & 0.00314 & -2.269 \\
\hline & Flood plains & 183,322 & 6898 & 0.03763 & -0.225 \\
\hline \multirow[t]{3}{*}{ Plane curvature } & Concave & 81,858 & 5711 & 0.06977 & 0.843 \\
\hline & Flat & 241,586 & 2514 & 0.01041 & -1.098 \\
\hline & Convex & 83,020 & 4021 & 0.04843 & 0.478 \\
\hline \multirow[t]{3}{*}{ Geology } & Unconsolidated sands, silts and clay & 100,716 & 2129 & 0.02114 & -0.351 \\
\hline & Fine and medium sands & 29,073 & 103 & 0.00354 & -2.148 \\
\hline & Fragments of pebbles, boulder and gravels & 276,666 & 10,014 & 0.03620 & 0.182 \\
\hline \multirow[t]{6}{*}{ Elevation (meters) } & $40.0-50.0$ & 71,745 & 389 & 0.00542 & -1.711 \\
\hline & $50.0-60.0$ & 67,521 & 589 & 0.00872 & -1.321 \\
\hline & $60.0-70.0$ & 69,875 & 686 & 0.00982 & -1.118 \\
\hline & $70.0-80.0$ & 63,744 & 2806 & 0.04402 & 0.382 \\
\hline & $80.0-90.0$ & 94,328 & 3968 & 0.04207 & 0.336 \\
\hline & $90.0-100.0$ & 39,245 & 3808 & 0.09703 & 1.173 \\
\hline \multirow[t]{6}{*}{ Stream power index (SPI) } & $0.0-0.50$ & 21,306 & 148 & 0.00695 & -1.469 \\
\hline & $0.50-1.00$ & 32,167 & 245 & 0.00762 & -1.373 \\
\hline & $1.00-1.50$ & 107,725 & 897 & 0.00833 & -1.284 \\
\hline & $1.50-2.00$ & 202,552 & 1902 & 0.00939 & -1.203 \\
\hline & $2.00-2.50$ & 33,809 & 2801 & 0.08285 & 1.015 \\
\hline & $2.50-3.00$ & 8899 & 6253 & 0.70266 & 3.153 \\
\hline \multirow[t]{5}{*}{ Slope of length (LS) } & $0.01-0.07$ & 210,299 & 889 & 0.00423 & -2.014 \\
\hline & $0.07-0.81$ & 64,110 & 760 & 0.01185 & -0.933 \\
\hline & $0.81-2.50$ & 50,307 & 778 & 0.01547 & -0.666 \\
\hline & $2.50-5.00$ & 41,804 & 3789 & 0.09064 & 1.098 \\
\hline & $5.00-7.50$ & 39,488 & 6030 & 0.15270 & 1.627 \\
\hline \multirow[t]{5}{*}{ Topographical wetness index (TWI) } & $0.0-0.5$ & 98,745 & 210 & 0.00213 & -2.708 \\
\hline & $0.5-1.0$ & 44,985 & 213 & 0.00473 & -2.014 \\
\hline & $1.0-1.5$ & 73,394 & 1000 & 0.01363 & -0.836 \\
\hline & $1.5-2.0$ & 178,416 & 4800 & 0.02690 & -0.143 \\
\hline & $2.0-2.5$ & 10,912 & 6023 & 0.55196 & 2.912 \\
\hline \multirow[t]{9}{*}{ Aspect } & Flat & 34,237 & 563 & 0.01644 & -0.603 \\
\hline & North & 50,049 & 869 & 0.01736 & -0.567 \\
\hline & North-east & 52,036 & 786 & 0.01510 & -0.693 \\
\hline & East & 48,204 & 1114 & 0.02311 & -0.261 \\
\hline & South-east & 48,482 & 1206 & 0.02488 & -0.223 \\
\hline & South & 50,295 & 2500 & 0.04971 & 0.491 \\
\hline & South-west & 52,155 & 2800 & 0.05369 & 0.569 \\
\hline & West & 47,731 & 1865 & 0.03907 & 0.262 \\
\hline & North-west & 23,266 & 543 & 0.02334 & -0.257 \\
\hline \multirow[t]{9}{*}{ Land use and land cover (LULC) } & Barren land & 5476 & 2986 & 0.54529 & 2.899 \\
\hline & Agricultural land & 113,724 & 3500 & 0.03078 & 0.001 \\
\hline & Scrub land & 43,925 & 1103 & 0.02511 & -0.182 \\
\hline & Dense forest & 124,810 & 1268 & 0.01016 & -1.098 \\
\hline & Open forest & 106,884 & 1399 & 0.01309 & -0.836 \\
\hline & Waste land & 9576 & 1986 & 0.20739 & 1.933 \\
\hline & River & 2060 & 4 & 0.00194 & -2.759 \\
\hline & & Enpixni & Enpixsi & Dens map & \\
\hline & & 406,455 & 12,246 & 0.03013 & \\
\hline
\end{tabular}


method indicating the magnitude of the class of each predisposing factor. Positive or negative values of $W_{i}$ points out whether the considered class of each influential factor is relevant or not in the development of gullies, respectively.

\section{Geomorphology}

The geomorphology of the Garbheta is strongly controlled by geological and structural setting (Fig. 3a). The western sector consists of lateritic undulating landscape characterized by steep slopes, more than $15^{\circ}$ in average, and a high local relief resulting in severe drainage downcutting. Lateritic undulating landscape (Duricrust) has positive role of gully erosion $\left(W_{i}=1.875\right)$. Slopes have rectilinear-convex profiles and are often highly dissected by V-shaped valleys (Fig. 8). Conversely, gentle slopes characterize the central and eastern sectors of the area; denudational processes, mainly gullies and rill wash processes, substantially affect undulating slopes. Slope profiles are generally very articulated, with concave-convex shapes and mainly characterized by concave valley floor.

\section{Lithology and soil}

The great assortment of lithological types cropping out in the study area has been categorized into three classes based on their compositional and mechanical properties. Two classes of soil texture defined in the study area (Fig. 3b), the fine-medium $(71.4 \%)$ and the medium (28.6\%) classes are the most frequent. The results of our analysis also showed fragments of pebbles, boulder and gravels have positive roles on gully erosion process $\left(W_{i}=0.17\right)$ in the study area. The morphological analysis showed that Garbheta is affected by permanent gullies; they are often characterized by incisions with vertical sidewalls and depth of 10-20 m (Fig. 8).

Gullied areas were mainly characterized by dendritic and trellis drainage patterns. Soil properties showed that both the older alluvium $\left(W_{i}=0.03\right)$ and lateritic soil $\left(W_{i}=0.13\right)$ have the positive influence on gully occurrence (Table 1). The most evident and spectacular landforms related to gully erosion in the study area are represented by GanganirDanga badlands, almost exclusively developed into clayey litho types with a channel network mainly characterized by a dendritic pattern (Fig. 3c).

\section{Land use and land cover (LULC) characteristics}

Land use characteristics of the study site have been categorized into seven classes (Fig. 3d). Agricultural land of the study area is covered by $56.91 \%(20,100.51$
Hectares) and $24.76 \%$ (8741.7 hectares) area is covered by dense, degraded and open forest land. Consequently, the fallow land is covered by $8.58 \%$ (3029.76 hectares) and settlement area is enclosed by $3.57 \%$ (1261.44 hectares) of the entire study site. On the southern part of the study site Silai river is flowing from west to east direction covering an area of $1.17 \%$ (412.29 hectares) of the study site and the river bed constitute gets deposited by sand in an enclosed area of 248.58 hectares $(0.70 \%)$. The grass land is $4.31 \%$ (1523.97 hectares). Table 2 identified the error matrix of LULC image derived from the supervised classification technique. The overall classification accuracy and kappa statistics were 86.00 and $0.83 \%$, respectively.

Land use factor plays an important role in gully processes $\left(W_{i}=0.83\right)$, mainly on barren land $\left(W_{i}=1.35\right)$ and waste land $\left(W_{i}=0.93\right)$. Result of our analysis also showed that agricultural land and scrub land have positive influence on gully erosion, while river, dense forest and open forest have negative impact on gully erosion (Table 1).

\section{Elevation}

The elevation map of Garhbeta was derived from ASTER DEM. The altitudinal range of Garhbeta block is varied from 40-100 m (Fig. 4a). Based on the elevation characteristics, the study area has been divided into six categories with $10 \mathrm{~m}$ interval. The highest elevation is observed the southern part of the study site, whereas the more than $70 \mathrm{~m}$ elevation determined the positive value of gully erosion.

\section{Aspect and plan curvature}

The aspect classes of the study area show a fairly homogeneous distribution (Fig. 4b). East and south-east facing slopes are comparatively less frequent. Plan curvature determines the curvature of a contour line formed by intersecting a horizontal plane with the surface (Wilson and Gallant 2000). Positive values of plan curvatures indicating the convexity; whereas the concavity of slope is determined the negative values of plan curvatures. The result of our analysis showed most of the gully eroded area in Garhbeta block is closely associated with the concave slopes (Fig. 4c).

\section{Length of slope factor}

The spatial pattern of the LS factor is shown in Fig. $4 d$ and its values have been classified in five classes. Table 1 showed that gullies commonly occur on slopes with high LS values. Slopes facing from east to south-east slightly 

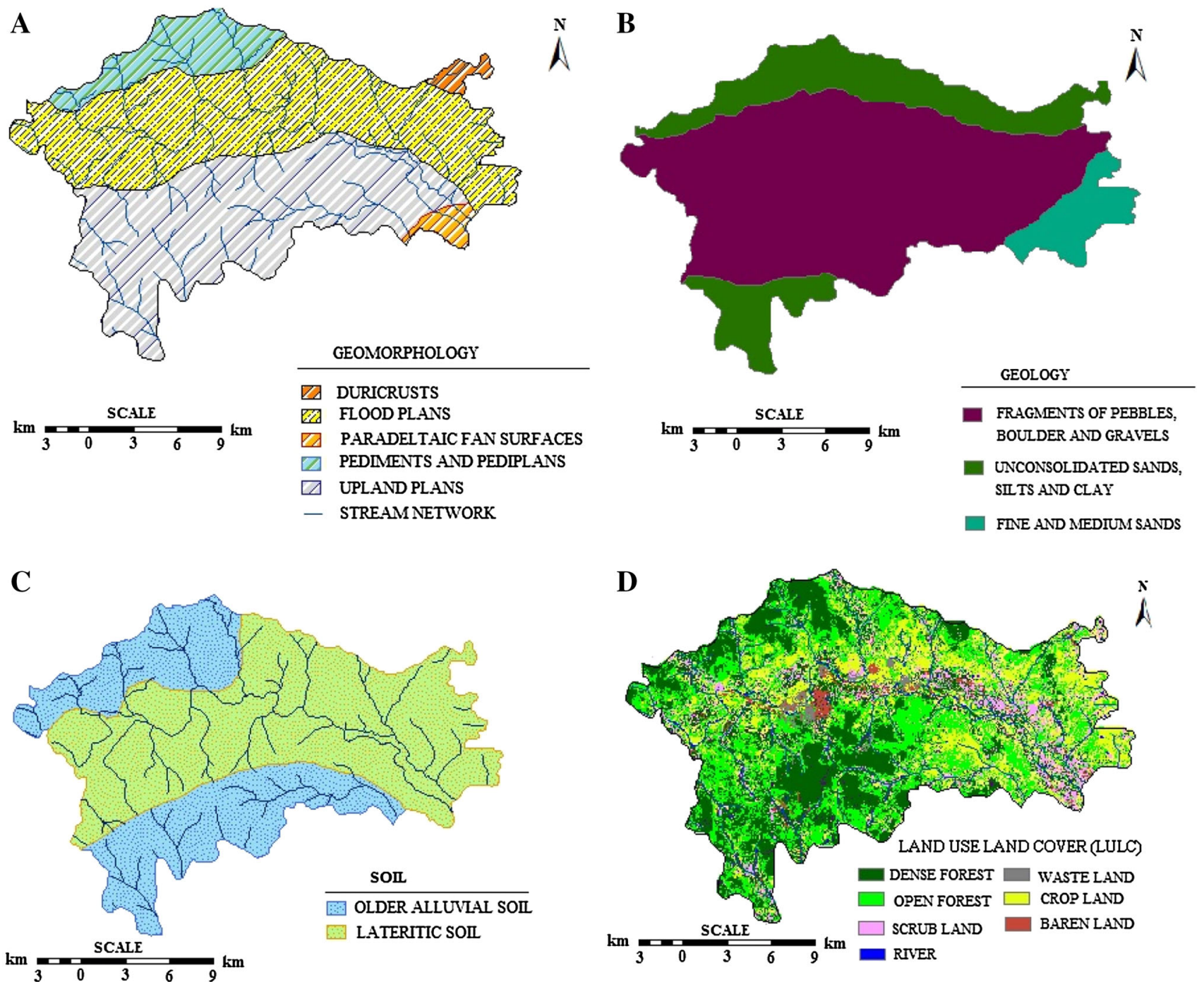

Fig. 3 Physical characteristic of the study area, a geology, b geomorphology, $\mathbf{c}$ soil and $\mathbf{d}$ land use and land cover

Table 2 Land use and land cover (LULC) characteristics and accuracy report of LULC of Garhbeta block

\begin{tabular}{|c|c|c|c|c|c|c|}
\hline Class Name & Number of pixels & Area (in hectares) & Percent & Producer accuracy $(\%)$ & User accuracy $(\%)$ & $\mathrm{Kappa}^{\wedge}$ \\
\hline Baren land & 5476 & 48.072 & 1.347 & 66.67 & 100.00 & 1.00 \\
\hline Agricultural land & 113,724 & 998.346 & 27.979 & 83.33 & 71.43 & 0.68 \\
\hline Scrub land & 43,925 & 385.603 & 10.807 & 100.00 & 84.21 & 0.77 \\
\hline Dense forest & 124,810 & 1095.666 & 30.707 & 88.89 & 100.00 & 1.00 \\
\hline Open forest & 106,884 & 938.300 & 26.297 & 66.67 & 100.00 & 1.00 \\
\hline Waste land & 9576 & 84.065 & 2.356 & 100.00 & 66.67 & 0.65 \\
\hline River & 2060 & 18.084 & 0.507 & 80.00 & 100.00 & 1.00 \\
\hline
\end{tabular}

Overall classification accuracy $=86.00 \%$

Overall kappa statistics $=0.8336$

predominate. The slope of a terrain refers to the amount of inclination of physical feature or topographic landform to the horizontal surface. Our results reveals that areas with high LS (>4.00) favours gully erosion.

\section{Topographical wetness index (TWI)}

The study area has been classified into five categories of TWI (Fig. 4e). Results showed that the maximum values of 

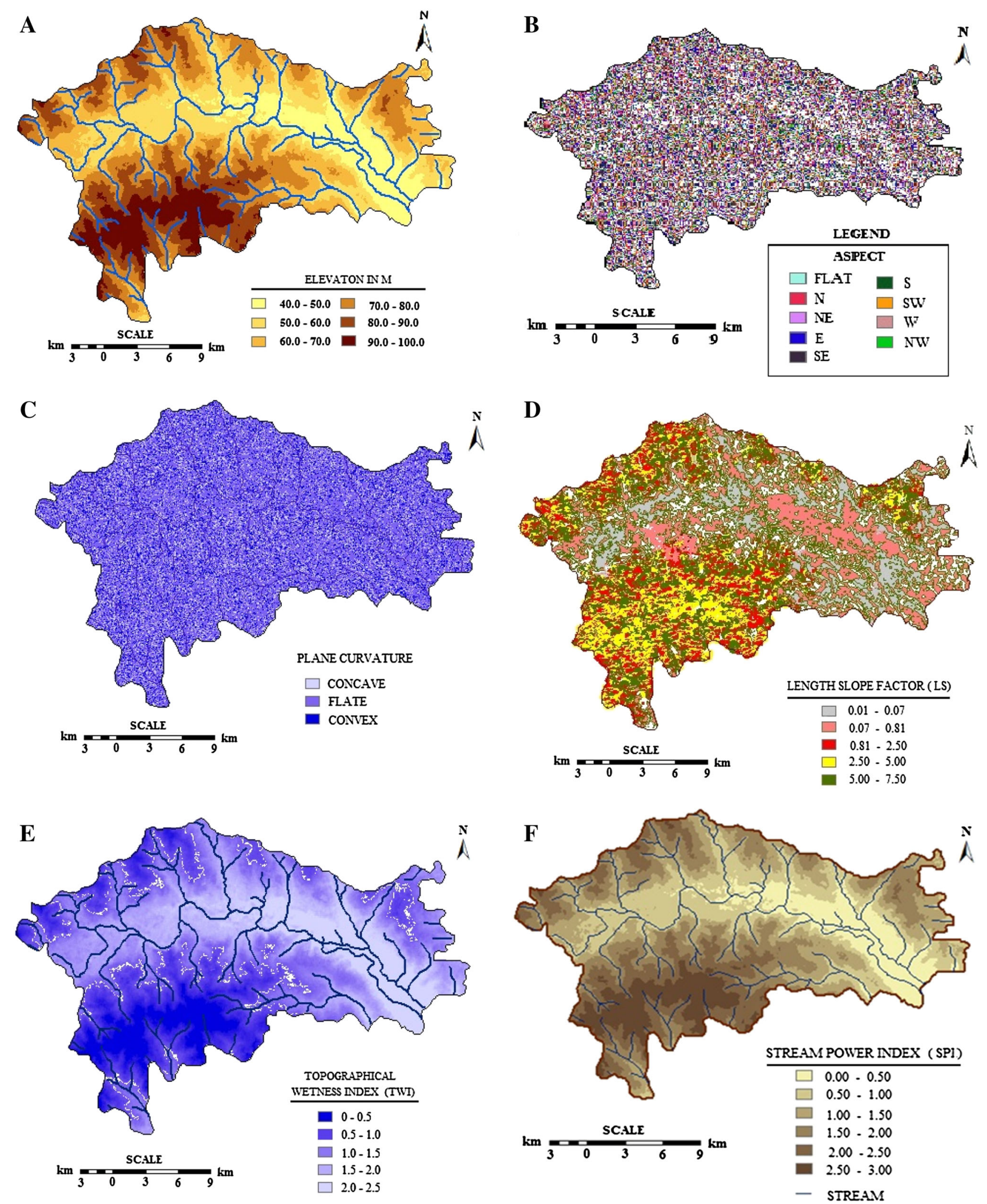

Fig. 4 Predisposing factors of gully erosion. a Elevation map; b land use land cover (LULC); c aspect map; $\mathbf{d}$ slope length factor (LS) map; e TWI map; and f SPI map 
TWI index have been predominantly evidenced in valley bottoms, terraced surfaces and gentle slopes. The study area in Garbheta badland is particularly favoured in areas with high TWI values $(>1.2)$. The higher value of TWI is portrayed in southwest and small pockets of northwest part.

\section{Stream power index (SPI)}

In the present research, values of SPI factor have been categorized into six classes. Table 1 showed that gully erosion processes normally crop up on slopes with high SPI values. The higher SPI value was recorded in the southwest, north and some small pockets of north-west part of the study area (Fig. 4f). Moreover, gully occurrence increases with an increase in SPI.

\section{Gully erosion susceptibility map}

Gully erosion susceptibility map of the study area is illustrated in Fig. 5. The index value of proneness ranges from 21.01 to 68.75 . Based on the geometric interval, the study area has been divided into five categories: very low (less that 25.00), low (25.01-29.85), moderate (29.86-35.15), high (35.16-39.94) and very high (more

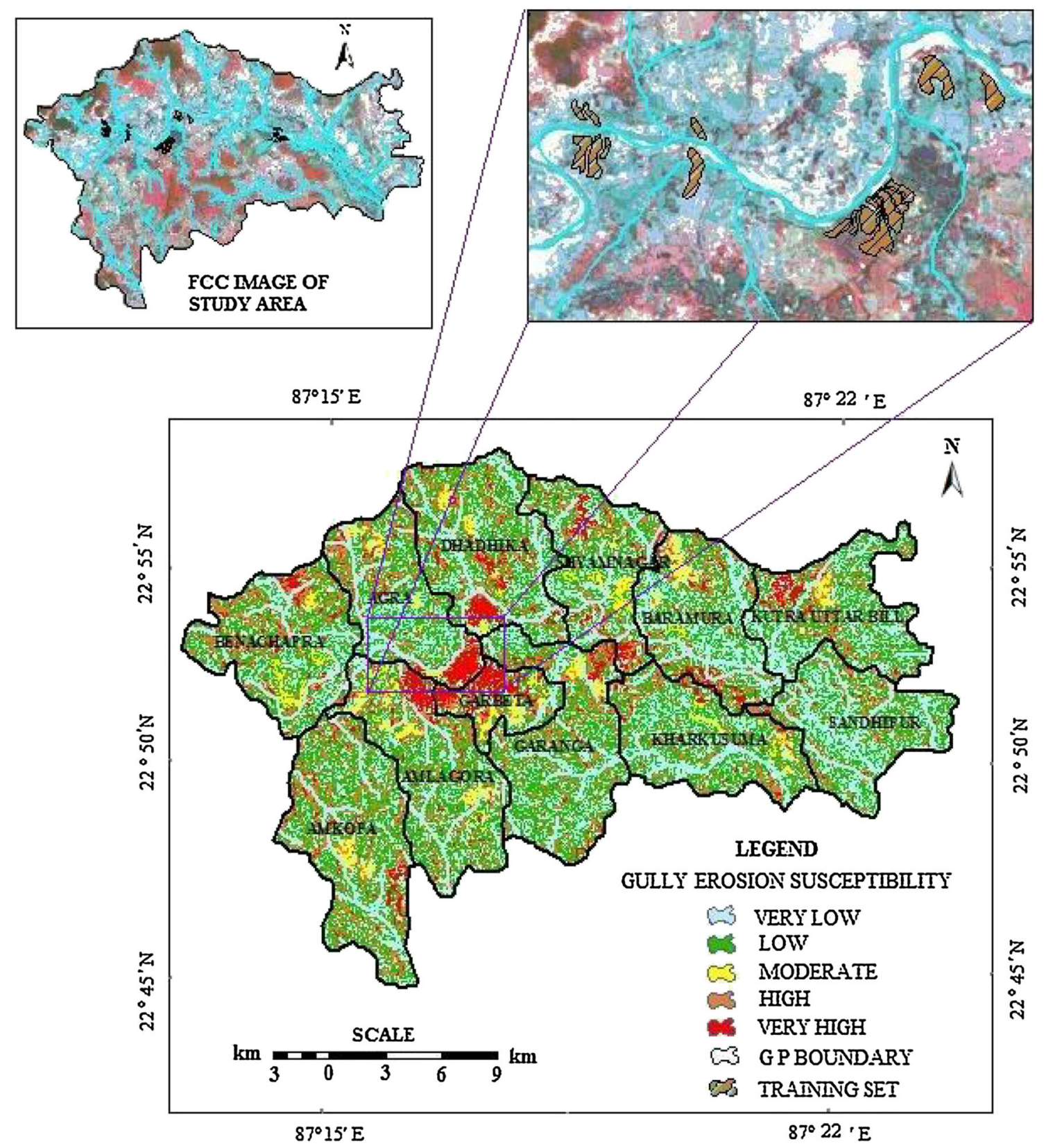

Fig. 5 Gully erosion susceptibility map of study area 
Fig. 6 Gram Panchayat (GP) wise spatial distribution of gully erosion
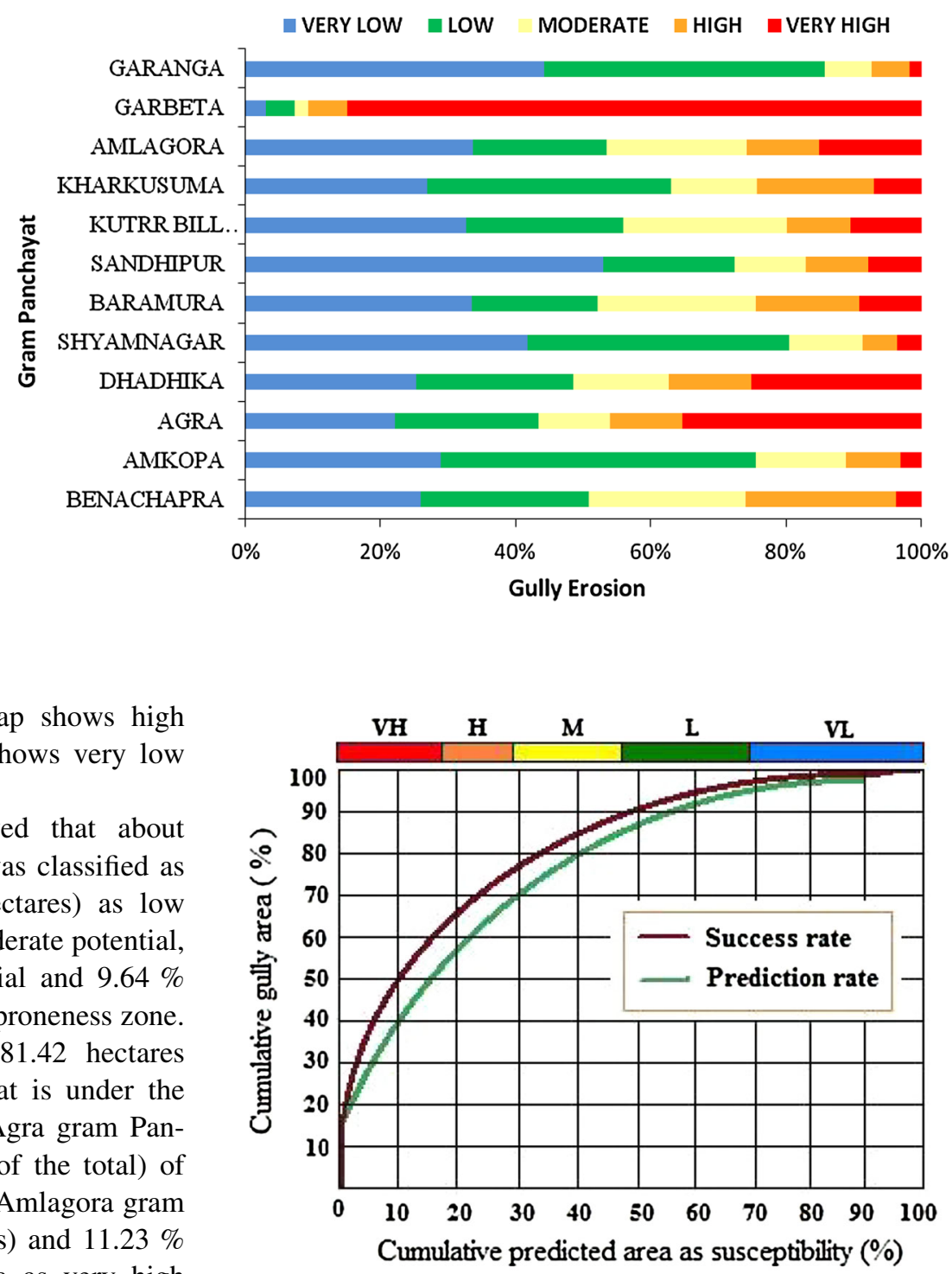

Fig. 7 Prediction rate and success rate curves that representing the accuracy of the susceptibility model of gully erosion

includes $51.25 \%$ of the total subsidence area of success rate curve and $49.86 \%$ of the prediction rate curve, while the $10 \%$ high gully proneness area covers more than $72.00 \%$ of the total gully area of success rate curve and $66.83 \%$ of the prediction rate curve.

\section{Discussion}

Topographical variables are the important driving factors of gully erosion. Gully sidewall crack development is potentially one of the most influential factors causing sidewall instability and failure in present study area (Fig. 9) (Shit et al. 2013a, b). Our study showed taht gully 

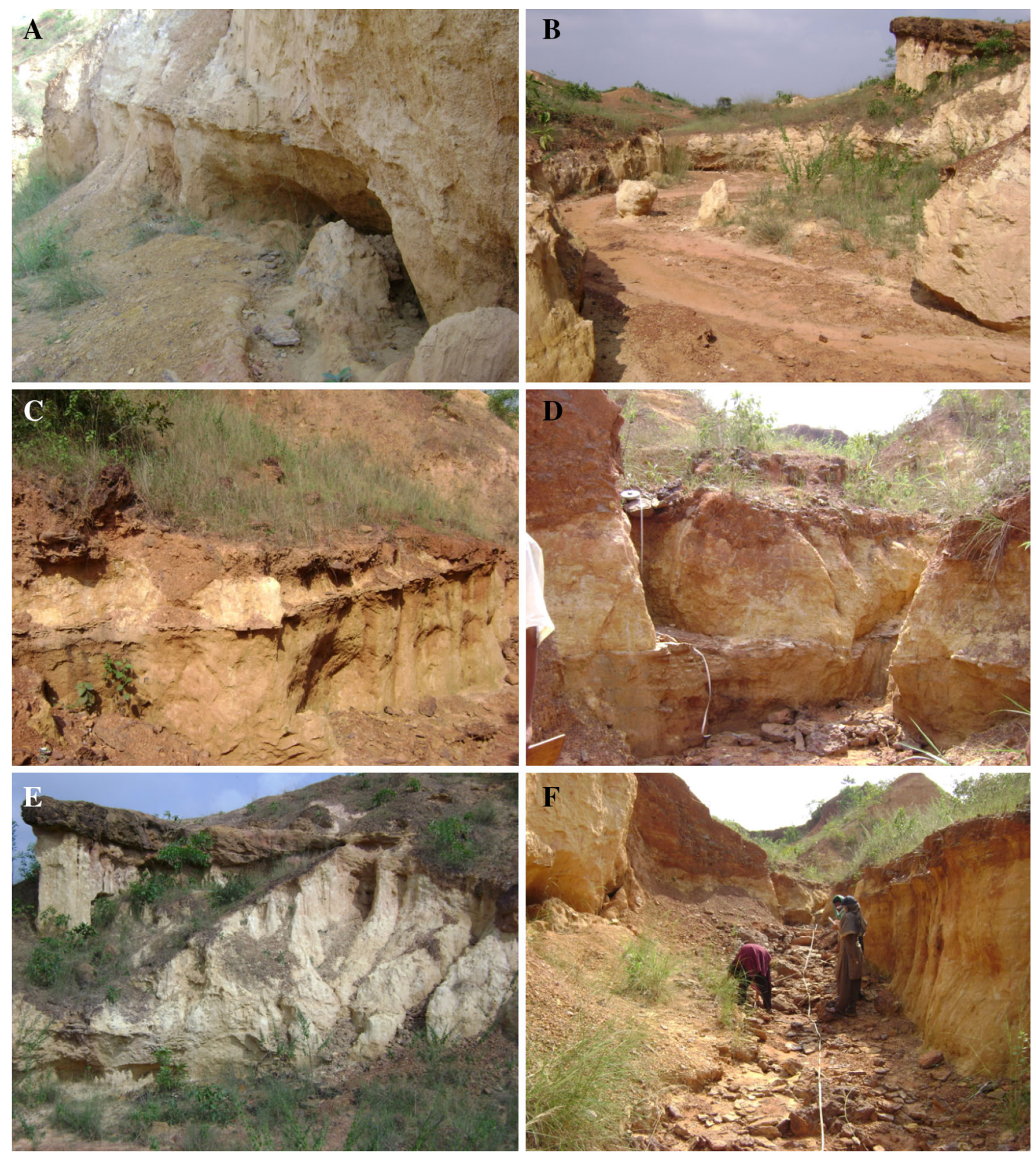

Fig. 8 Gully erosion processes in the Garbheta block. a Sidewall erosion, b gully widening, $\mathbf{c}$ active gully erosion during heavy rain events, d gully formed by retrogressive erosion with narrow and

V-shaped channels, e badlands in the clayey lithology, $\mathbf{f}$ debris flow cones accumulated at the gully bottom of badlands channels

formation is often enhanced from June to September during monsoon period and with more than $20^{\circ}$ slope gradient. However, the present result is corroborated with previous study carried out by Bandyopadhyay (1998) in other regions of West Bengal. Site-specific factors such as gully bank height, soil properties, and the length of the drying period affect crack development (Oostwoud Wijdenes and Bryan, 1994; Shit and Maiti 2012b). Results illustrated in our study identified the slope with $>20^{\circ}$

having the maximum influence on gully occurrence. Field observations at Ganganir danga site indicated that much of the lateritic-exposed gully sidewalls are bounded by tension cracks, while sections exposing mineral sediment are free from cracking (Fig. 8). Both concentrated runoff, falls and topples are enhanced by the occurrence of desiccation cracks (due to shrink/swell dynamics of expandable clays) and tension cracks developed during dry seasons (Pulice et al. 2009). The presence of tension cracks on top of gully 

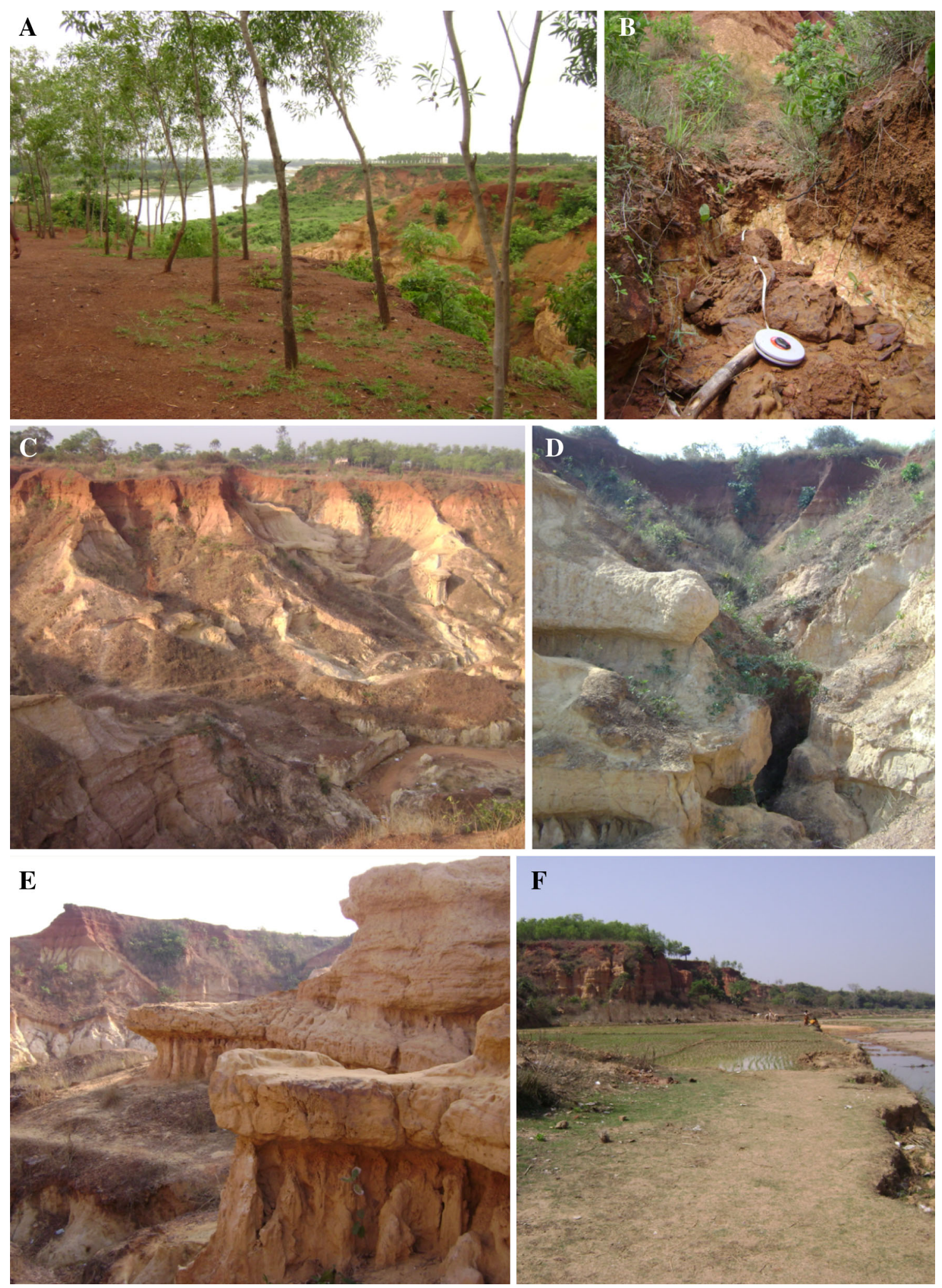

Fig. 9 Gully erosion processes at Ganganir Danga badland a gully erosion along the silai river, $\mathbf{b}$ gully headcut and flank retreat processes, $\mathbf{c}$ spectacular landforms related to gully erosion, $\mathbf{d}$ narrow and deep vertical gully erosion, e earth pillar of gully erosion and f encroachment of gully in agriculture field 
sides often tends to increase falling phenomena (Collison 2001; Bull and Kirkby 2002; Poesen et al. 2002; Shit and Maiti 2012a).

Steep slopes encourage high runoff velocity and resulting rill and gully initiation (Valentin et al. 2005). Slope analysis is an important parameter in morphometric studies (Gayen et al. 2013). Poesen et al. (2003) found that that critical drainage area or upslope contributing area (AS) needed for gully initiation decreases as slope steepens. Our results exhibited gully development largely depends on high AS values. Naturally, the areas with high AS values have attained the maximum values TWI (areas prone to become wet). The present information has been affirmed by the earlier study (BouKheir et al. 2007; Le Roux and Sumner 2012), representing zones of saturation with high surface soil water along drainage paths where AS is high and slope is low. These saturated areas favour gully formation since the surface soils lose their strength as they become wet. SPI indicates the catchment area of concentrated runoff (Morgan 1995) and thus the higher the SPI the higher the chance of a gully occurring.

The length-slope index (LS) also combines the effects of AS and slope. The gradient of slopes is one of the primary importance in the dynamics of the processes overriding land evolution; in fact, it affects surface runoff, drainage density, soil erosion, etc. (Rieke-Zapp and Nearing 2005; Conforti et al. 2011). Fluvial undercutting and the consequent collapse of gully sidewalls cause dilatation (pressure release) crack development and exposes under rocks. However, during heavy rain events, many gullies reactivate and, in addition to vertical dissection, may frequently undergo headcut and valley-side retreat processes causing lengthening, deepening and widening of gullies (Fig. 9). In the present analysis, high proportion of gullied were found in high LS areas. It may be due to the generation of sufficient runoff (high AS) with a sufficient level of relief energy (Desmet et al. 1999).

Fragments of pebbles, boulder and gravels are the most widespread lithologies in the area under study. Unconsolidated sand, silt and clays crop out for the $12 \%$ of the study area and mostly in the northern and extreme southern zone. Fine and medium sands mainly outcrop in the southeast pocket of the basin reaching about $3 \%$ of the basin. Tamene et al. (2006) reported that the inherent erodibility of the parent material (Geology) as the overriding gully erosion risk factor. In Garbheta various lateritic/sandstones were susceptible to gully erosion mainly due to highly erodible soils.

Gully erosion is often triggered by appropriate land use characteristics. Field observations indicated that a relatively large portion of the cultivated and scrub areas in the catchment are affected by gully erosion due to livestock disturbance, including overgrazing and trampling along cattle tracks. Present results also corroborated with the previous study conducted by Boardman and Foster (2008); Gómez Gutiérrez et al. (2009a, b).

The analysis illustrated that both the curves have very analogous shape, viewing an elevated gradient in the earliest part and smoothly lessen monotonically. However, this analysis also proves strong spatial relationship between influential factors used in the present analysis. Moreover, the validation method demonstrates that the projecting power of the model is accurately portrayed in high and very high risk areas.

\section{Conclusions}

This study aimed to identity the most influential factors of gully erosion and to delineate susceptible zone based on bivariate statistical method and geospatial technology. The analysis performed has revealed that various factors have different influence on gully development. Our results suggested that topographical factors and land use characteristics played an imperative role on gully occurrence in Garhbeta block (Paschim Medinipur, West Bengal, India). Moreover, for each factor, only some classes were found to play a very important role in the development of gully. The most contributing classes to gully occurrences were found to be: lateritic soil, concave slope, fragmentation of pebbles, boulders and gravels, elevation $(70-90 \mathrm{~m})$, stream power index $(2.00-3.00)$, slope of length (2.50-7.50), TWI (2.0-2.5), waste and barren land areas. Our results confirm that the high value of the gully proneness map demonstrated reasonable concurrence with the gully site data.

As such, the proposed model helps to decision makers to delineate the high and low susceptible areas in relation to gully erosion and to develop suitable soil and water conservation practices. The prediction rate curve portrayed satisfactory agreement between the gully erosion prone map and gully location data obtained from the field. This methodology can also be used in the other areas to delineate the gully susceptible zone.

\section{References}

Bandyopadhyay S (1998) Drainage Evolution in Badland Terrain at Gangani in Medinipur District, West Benagl. Geogr Rev India 50(3):10-20

Barbieri, G., Cambuli, P (2009) The weight of evidence statistical method inlandslide susceptibility mapping of the Rio Pardu Valley (Sardinia, Italy). In: Proceedings of the 18th World IMACS/MODSIM Congress, held in Cairns, Australia. pp. $2658-2664$ 
Boardman J, Foster I (2008) Badland and gully erosion in the Karoo, South Africa. J Soil Water Conserv 63:121A-125A

Boardman J, Parsons AJ, Holland R, Holmes PJ, Washington R (2003) Development of badlands and gullies in the Sneeuberg Great Karoo, South Africa. Catena 50:165-184

BouKheir R, Wilson J, Deng Y (2007) Use of terrain variables for mapping gully erosion proneness in Lebanon. Earth Surf Process Landforms 32:1770-1782

Bull J, Kirkby MJ (2002) Channel heads and channel extension. In: Bull LJ, Kirkby MJ (eds) Dryland Rivers: hydrology and geomorphology of semi-arid channels. Wiley, Chichester, pp 263-298

Cevik E, Topal T (2003) GIS-based landslide proneness mapping for a problematic segment of the natural gas pipeline, Hendek (Turkey). Environ Geol 44:949-962

Chaplot V, Giboire G, Marchand P, Valentin C (2005) Dynamic modellingforlinear erosion initiation and development under climate and land-use changesin Northern Laos. Catena 63:318-328

Chung CF, Fabbri AG (2003) Validation of spatial prediction models for landslide hazard mapping. Nat Hazards 30:451-472

Collison AJC (2001) The cycle of instability: stress release and fissure flow as controls on gully head retreat. Hydrol Process 15:3-12

Conforti M, Aucelli PPC, Robustelli G, Scarciglia F (2011) Geomorphology and GIS analysis for mapping gully erosion proneness in the Turbolo stream catchment (Northern Calabria, Italy). Nat Hazards 56:881-898

Conoscenti C, Di Maggio C, Rotigliano E (2008) Soil erosion proneness assessment and validation using a geostatistical multivariate approach: a test in Southern Sicily. Nat Hazards 46:287-305

Conoscenti C, Angileri S, Cappadonia C, Rotigliano EV, Märker M (2013) Gully erosion proneness assessment by means of GISbased logistic regression: a case of Sicily (Italy). Geomorphology. doi:10.1016/j.geomorph.2013.08.021

Dai FC, Lee CF, Li J, Xu ZW (2001) Assessment of landslide proneness on the natural terrain of Lantau Island, Hong Kong. Environ Geol 40:381-391

Desmet PJJ, Poesen J, Govers G, Vandaele K (1999) Importance of slope gradient and contributing area for optimal prediction of the initiation and trajectory of ephemeral gullies. Catena 37:377-392

Dey S, Ghosh S, Debbarma C and Sarker P (2009) Some observation of regional evidences of Tertiary-Quaternary geo-dymanics in a paleo-coastal of Bengal basin, India. Russian Geol Geophys $50(11)$

Dube F, Nhapi I, Murwira A, Gumindoga W, Goldin J, Mashauri DA (2014) Potential of weight of evidence modelling for gully erosion hazard assessment in Mbire District-Zimbabwe. Phys Chem Earth 67-69:145-152

El Baroudy AA, Moghanm FS (2014) Combined use of remote sensing and GIS for degradation risk assessment in some soils of the Northern Nile Delta. J Remote Sensing Space Sci, Egypt. doi:10.1016/j.ejrs.2014.01.001

FAO, UNESCO (1974) FAO-UNESCO Soil Map of the World, Legend, vol 1. UNESCO, Paris

Frankl A, Zwertvaegher A, Poesen J, Nyssen J (2013) Transferring Google Earth observations to GIS-software: example from gully erosion study. Int J Digital Earth 6(2):196:201. doi:10.1080/ 17538947.2012.744777

Gayen S, Bhunia GS, Shit PK (2013) Morphometric Analysis ofKangshabati-Darkeswar Interfluves Area in West Bengal, India using ASTER DEMand GIS Techniques. J Geol Geo Sci 2:133. doi:10.4172/2329-6755.1000133

Gómez Gutiérrez Á, Schnabel S, Felicísimo ÁM (2009a) Modelling the occurrence of gullies in rangelands of southwest Spain. EarthSurf.Process. Landforms 34:1894-1902
Gómez Gutiérrez Á, Schnabel S, LavadoContador F (2009b) Gully erosion, land use and topographical thresholds during the last 60 years in a small rangeland catchment in SW Spain. Land Degrad Dev 20:535-550

Gumindoga W, Rwasoka DT, Murwira A (2011) Simulation of streamflow using TOPMODEL in the Upper Save River catchment of Zimbabwe. Phys Chem Earth Parts A/B/C 36(14-15):806-813

Kakembo V, Xanga WW, Rowntree K (2009) Topographic thresholds in gully development on the hillslopes of communal areas in Ngqushwa Local Municipality, Eastern Cape, South Africa. Geomorphology 110:188-195

Laker MC (2004) Advances in soil erosion, soil conservation, land suitability evaluation and land use planning research in South Africa, 1978-2003. S Afr J Plant Soil 21:345-368

Le Roux JJ, Sumner PD (2012) Factors controlling gully development: comparing continuous and discontinuous gullies. Land Degrad Develop 23:440-449

Lee S (2004) Soil erosion assessment and its verification using the Universal Soil Loss Equation and geographic information system: a case study at Boun, Korea. Environ Geol 45:457-465

Marzolff I, Ries JB, Poesen J (2011) Short-term versus medium-term monitoring for detecting gully-erosion variability in a Mediterranean environment. Earth Surf Process. Landforms 36:1604-1623

Mitasova H, Hofierka J, Zlocha M, Iverson RL (1996) Modeling topographic potential for erosion and deposition using GIS. Int J Geogr Inf Sci 10(5):629-641

Moore ID, Burch GJ (1986) Physical basis of the length-slope factor in the universal soil loss equation. Soil Sci Soc Am J 50:1294-1298

Moore ID, Grayson RB, Ladson AR (1991) Digital terrain modelling: a review of hydrological, geomorphological, and biological applications. Hydrol Process 5:3-30

Morgan RPC (1995) Soil erosion and conservation. Longman, Group Ltd, ESSEX

Nagarajan R, Roy A, Vinod Kumar R, Mukherjee A, Khire MV (2000) Landslide hazard suspectibility mapping based on terrain and climatic factors for tropical monsoon regions. Bull Engl Geol Env 58:275-287

Nasre RA, Nagaraju MSS, Srivastava R, Maji AK, Barthwal AK (2013) Soil erosion mapping for land resources management in Karanji watershed of Yavatmal district, Maharashtra using remote sensing and GIS techniques. Indian $\mathrm{J}$ of Soil Cons 41(3):248-256

Nefeslioglu HA, Duman TY, Durmaz S (2008) Landslide proneness mapping for a part of tectonic Kelkit Valley (Eastern Black Sea region of Turkey). Geomorphology 94:401-418

Niyogi D (1970) Geological background of beach erosion of Digha, West Bengal. Bull Geol Mining Metall Soc India 43:1-36

Okalp K (2005) Soil erosion risk mapping using geographic information systems: a case study on Kocadere creek watershed, Izmir. M.Sc. Thesis. Department of Geodetic and Geographic Information Technologies, Natural and Applied Sciences of Middle East Technical University. Ankara, Turkey, pp 20-21

OostwoudWijdenes DJ, Bryan RB (1994) Gully headcuts as sediment sources on the Njemps flats and initial low-cost gully control measures. Catena Suppl 27:205-229

Pal AK (2002) Coastal Geomorphology and Environment. ACB Publications, Kolkatta

Poesen J (1993) Gully typology and gully control measures in the European loess belt. In: Wicherek S (ed) Farm Land Erosion in Temperate Plains Environment and Hills. Elsevier, Amsterdam, pp 221-239

Poesen J, Vandekerckhove L, Nachtergaele J, OostwoudWijdenes D, Verstraeten G, Van Wesemael B (2002) Gully erosion in dryland 
environments. In: Bull LJ, Kirkby MJ (eds) Dryland Rivers: hydrology and geomorphology of semi-arid channels. Wiley, Chichester, pp 229-262

Poesen J, Nachetergaele J, Verstraeten J, Valentin C (2003) Gully erosion andenvironmental change: importance and research needs. Catena 50(2-4):91-133

Prasannakumar V, Vijith H, Abinod S, Geetha N (2012) Estimation of soil erosion risk within a small mountainous sub-watershed in Kerala, India, using Revised Universal Soil Loss Equation (RUSLE) and geo-information technology. Geosci Front 3(2):209-215

Pulice I, Scarciglia F, Leonardi L, Robustelli G, Conforti M, Cuscino M, Lupiano V, Critelli S (2009) Studio multidisciplinare di forme e processidenudazionalinell'area di Vrica (Calabria orientale). BollettinodellaSocieta“ GeograficaItaliana 87(III):399-414

Regmi NR, Giardino JR, Vitek JD (2010) Modelling susceptibility to landslidesusing the weight of evidence approach: western Colorado USA. Geomorphology 115:172-187

Remondo J, Gonzalez A, Teran J, Cendrero A, Fabbri A, Chung C (2003) Validation of landslide proneness maps; examples and applications from a case study in Northern Spain. Nat Hazards 30:437-449

Rieke-Zapp DH, Nearing MA (2005) Slope shape effects on erosion: a laboratory study. Soil Science Soci Am 69:1463-1471

Rogan J, Franklin J, Roberts DA (2002) A comparison of methods for monitoring multitemporal vegetation change using Thematic Mapper imagery. Remote Sens Environ 80(1):143-156

Sen J, Sen S, Bandyopadhyay S (2004) Geomorphological investigation of badlands- a case study at Garbheta, West Medinipur District, West Bengal, India. In Singh S, Sharma HS, De SK (eds) Geomorphology and environment. ACB publication, Kolkata, pp 204-234

Shit PK, Maiti R (2012a) Mechanism of Gully-Head Retreat-A Study at GanganirDanga, PaschimMedinipur, West Bengal. Ethiopian J Environ Studies Manag 5(4):332-342

Shit PK, Maiti R (2012b) Rill Hydraulics-An Experimental Study on Gully Basin in Lateritic Upland of PaschimMedinipur, West Bengal, India. J Geogr Geol 4(4):1-11. doi:10.5539/jgg.v4n4p1

Shit PK, Bhunia G, Maiti R (2013a) Assessment of Factors Affecting Ephemeral Gully Development in Badland Topography: a Case
Study at Garbheta Badland (PashchimMedinipur. Int J Geosci 4(2):461-470. doi:10.4236/ijg.2013.42043

Shit PK, Bhunia GS, Maiti R (2013b) Assessing the performance of check dams to control rill-gully erosion: small catchment scale study. Int J Curr Res 5(4):899-906

Shit PK, Bhunia G, Maiti R (2014) Morphology and development of selected Badlands in South Bengal (India). Indian J Geogr Environ 13:161-171

Sinha D, Joshi V (2012) Application of Universal Soil Loss Equation (USLE) to Recently Reclaimed Badlands along the Adula and Mahalungi Rivers, Pravara Basin, Maharashtra. J Geol Soc India 80:341-350

Tamene L, Park SJ, Dikau R, Vlek PLG (2006) Analysis of factors determining sediment yield variability in the highlands of northern Ethiopia. Geomorphology 76:76-91

Valentin C, Poesen J, Li Y (2005) Gully erosion: impacts, factors and control. Catena 63:132-153. doi:10.1016/j.catena.2005.06.001

Van Westen CJ (1993) Application of geographic information systems to landslide hazard zonation. ITC publ. no. 15, Int. Ins. for Aerospace and Earth Res. Surv, Enschede. The Netherlands, pp 245

Vanwalleghem T, Poesen J, Nachtergaele J, Verstraeten G (2005) Characteristics, controlling factors and importance of deep gullies under cropland on loess.derived soils. Geomorphology 69:76-91

Vrieling A, Sterk G, Beaulieu N (2002) Erosion risk mapping; a methodological case study in the Colombian Eastern Plains. J Soil Water Conserv 57(3):158-163

Wilson JP, Gallant JC (2000) Terrain analysis principles and applications. Wiley, Toronto, p 479

Yalcin A (2008) GIS-based landslide proneness mapping using analytical hierarchy process and bivariate statistics in Ardesen (Turkey): comparison of results and confirmations. Catena 2:1-12

Yin KJ, Yan TZ (1988) Statistical prediction model for slope instability of metamorphosed rocks. In: Proceedings of the 5th international symposium on landslides, vol 2. Lausanne, Switzerland, pp 1269-1272

Yuksel A, Akay AE, Gundogan R, Reis M, Cetiner M (2008) Application of GeoWEPP for Determining Sediment Yield and Runoff in the Orcan Creek Watershed in Kahramanmaras, Turkey. Sensors. 8:1222-1236 